Vol. 11 (2002): 107-119.

\title{
Dietary preferences of weaned piglets offered diets containing organic acids
}

\author{
Kirsi Partanen, Hilkka Siljander-Rasi and Kaija Suomi \\ MTT Agrifood Research Finland, Animal Production Research, Pigs, Tervamäentie 179, \\ FIN-05840 Hyvinkää, Finland, e-mail: kirsi.partanen@mtt.fi
}

\begin{abstract}
A preference test and a performance trial were carried out to examine weaned piglets' feed intake response to diets containing either lactic acid, formic acid, calcium formate, or sodium benzoate ( $8 \mathrm{~g}$ $\mathrm{kg}^{-1}$ feed). In Experiment 1, throughout a 21-d post-weaning period, 30 entire litters (306 piglets) weaned at the age of $30 \mathrm{~d}$ were allowed to choose between two organic-acid-supplemented diets. All of the four different organic-acid-supplemented diets were tested in pairs against each other, and the six possible combinations were lactic acid + formic acid, lactic acid + calcium formate, lactic acid + sodium benzoate, formic acid + calcium formate, formic acid + sodium benzoate, and calcium formate + sodium benzoate. Piglets preferred diets supplemented with sodium benzoate to ones supplemented with formic acid or calcium formate. The acceptability of diets supplemented with lactic acid, formic acid, or calcium formate was similar. In Experiment 2, until the age of $58 \mathrm{~d}, 60$ piglets from 10 litters weaned at the age of 28 or $38 \mathrm{~d}$ were fed non-acidified diets or ones supplemented with lactic acid, formic acid, calcium formate, or sodium benzoate. Feed consumption did not differ between piglets fed non-acidified and those fed organic-acid-supplemented diets. Growth performance was reduced by dietary calcium formate supplementation, while the performance of piglets fed other organic-acid-supplemented diets did not differ significantly from those fed the non-acidified control diet. The frequency of post-weaning diarrhoea was highest in piglets fed diets supplemented with calcium formate and lowest in piglets fed diets supplemented with formic acid.
\end{abstract}

Key words: calcium formate, diarrhoea, formic acid, lactic acid, palatability, sodium benzoate

\section{Introduction}

Considerable research has addressed the topic of including organic acids in diets for weaned piglets to improve their performance. In general, dietary organic acids appear to improve the growth and feed-to-gain ratio of weaned piglets, but these responses can vary greatly depending on the type and amount of acid used, diet composition, weaning age, and the animals' health status (Ravindran and Kornegay 1993). In data consisting of 46 published performance trials, the growth response of weaned piglets to dietary organic acids was closely associated with these acids' influence on feed intake $(r=0.77, \mathrm{P}$

(C) Agricultural and Food Science in Finland

Manuscript received February 2002 


\section{AGRICULTURAL AND FOOD SCIENCE IN FINLAND}

\section{Partanen, K. et al. Weaned piglets offered diets containing organic acids}

$<0.001$ ) (Partanen 2001). The feed intake of weaned piglets was enhanced by dietary formic acid and potassium diformate supplementations, whereas citric and fumaric acid supplementations had no effect compared to the non-acidified control diet (Partanen 2001). Other organic acids, e.g. lactic and sorbic acid, have also been reported to enhance the feed intake of weaned piglets (Roth et al. 1993, Kirchgessner et al. 1995), whereas tartaric acid, which has a strong odour and flavour, decreases feed intake compared to the non-acidified control diet (Kirchgessner et al. 1993). According to Pluske et al. (1995), the level of voluntary feed intake during the immediate post-weaning period is crucial for the subsequent performance. Although the choice of organic acid appears to affect the palatability of organic-acid-supplemented diets, the preference of weaned piglets for different organic acids has not been much investigated. In the study of Henry et al. (1985), piglets preferred non-acidified diets when they were able to choose freely between non-acidified diets and diets supplemented with citric acid $\left(30 \mathrm{~g} \mathrm{~kg}^{-1}\right)$ or fumaric acid $\left(15 \mathrm{~g} \mathrm{~kg}^{-1}\right)$. When only a single diet was offered, piglets ate most citric-acid-supplemented diets.

The first aim of this study was to investigate whether weaned piglets are able to differentiate or demonstrate a preference for a specific organic acid when given a free choice of two acidified weaner diets containing either lactic acid, formic acid, calcium formate, or sodium benzoate. The second objective was to investigate the performance response of weaned piglets to diets supplemented with the aforementioned organic acids.

\section{Material and methods}

\section{Experiment I}

Thirty entire litters (306 piglets) were used in a choice-feeding trial to determine the relative consumption of diets containing lactic acid, formic acid, calcium formate, or sodium benzoate. The experiment was begun at weaning and was continued for 21 days. All of the four different acid supplements were tested in pairs against each other in order to test all six possible combinations: 1) lactic acid + formic acid, 2) lactic acid + calcium formate, 3 ) lactic acid + sodium benzoate, 4) formic acid + calcium formate, 5) formic acid + sodium benzoate, and 6) calcium formate + sodium benzoate. Each combination was tested with five entire litters with a minimum of eight piglets at weaning.

At the age of 30 days, piglets were weaned to farrowing pens, where they were housed throughout the trial. Wood shavings were used as bedding material. There was a heating lamp, which was removed when the piglets were six weeks old. When the piglets were 14 days old, two identical gravity flow feeders were placed into the pen that both provided a non-acidified basal diet ad libitum. The composition of the basal diet is presented in Table 1. At weaning, two different acidified diets were placed into the feeders depending on the combination of diets to be tested. The location of the acidified diets varied from pen to pen but was kept constant within the pen. The acidified diets were prepared by supplementing the basal diet with $8 \mathrm{~g} \mathrm{~kg}^{-1}$ of lactic acid (80-85\%), formic acid (80-90\%), calcium formate, or sodium benzoate. All feeds were cold pelleted (Amandus Kahl Labourpresse, $4 \mathrm{~mm}$ die). Feed disappearance from both feeders was determined separately on days 1, 2, $3,4,5,6,7,9,11,13,15,18$, and 21 after weaning. No determination of feed wastage was possible. Piglets were weighed at birth, weaning, and 7 and 21 days after weaning.

\section{Experiment 2}

A total of 60 weaned piglets from 10 litters were used in the trial. The litters were divided into two replicates according to the weaning age (28 or 38 days). Within these replicates, six piglets from each litter were randomly allotted to three 
Vol. 11 (2002): 107-119.

Table 1. Ingredients and calculated composition of basal diets in Experiments 1 and 2.

\begin{tabular}{|c|c|c|}
\hline & Experiment 1 & Experiment 2 \\
\hline \multicolumn{3}{|l|}{ Ingredients, $\mathrm{g} \mathrm{kg}^{-1}$ feed } \\
\hline Barley & 378.6 & 350.0 \\
\hline Wheat & 400.0 & 343.0 \\
\hline Oat meal & - & 100.0 \\
\hline Soya bean meal & 106.1 & 80.0 \\
\hline Low lactose whey powder (CP $250 \mathrm{~g} \mathrm{~kg}^{-1}$, lactose $\left.380 \mathrm{~g} \mathrm{~kg}^{-1}\right)$ & 30.0 & - \\
\hline Whey protein concentrate (CP $730 \mathrm{~g} \mathrm{~kg}^{-1}$, lactose $120 \mathrm{~g} \mathrm{~kg}^{-1}$ ) & & 76.0 \\
\hline Fish meal & 60.0 & 20.0 \\
\hline Limestone & 9.7 & 11.4 \\
\hline Monocalcium phosphate & 1.6 & 6.9 \\
\hline L-Lysine $\mathrm{HCl}$ & 1.7 & - \\
\hline Mineral and vitamin premix ${ }^{1}$ & 12.4 & 13.0 \\
\hline \multicolumn{3}{|l|}{ Calculated composition } \\
\hline Net energy, $\mathrm{MJ} \mathrm{kg}^{-1}$ & 9.2 & 9.5 \\
\hline Crude protein, $\mathrm{g} \mathrm{kg}^{-1}$ & 186 & 195 \\
\hline Ileal digestible lysine, $\mathrm{g} \mathrm{kg}^{-1}$ & 9.3 & 9.7 \\
\hline Ileal digestible threonine, $\mathrm{g} \mathrm{kg}^{-1}$ & 5.6 & 7.2 \\
\hline Ileal digestible methionine and cystine, $\mathrm{g} \mathrm{kg}^{-1}$ & 5.6 & 6.5 \\
\hline Calcium, $\mathrm{g} \mathrm{kg}^{-1}$ & 9.0 & 9.2 \\
\hline Phosphorus, $\mathrm{g} \mathrm{kg}^{-1}$ & 5.5 & 5.9 \\
\hline \multicolumn{3}{|l|}{$\mathrm{CP}=$ crude protein.} \\
\hline \multicolumn{3}{|c|}{$\begin{array}{l}\text { Ten grams of premix contained the following minerals and vitamins: } 1.8 \mathrm{~g} \mathrm{Ca}, 0.6 \mathrm{~g} \mathrm{P}, 0.4 \mathrm{~g} \mathrm{Mg}, 2.5 \mathrm{~g} \mathrm{NaCl}, 79 \mathrm{mg} \mathrm{Fe} \\
17 \mathrm{mg} \mathrm{Cu}, 70 \mathrm{mg} \mathrm{Zn}, 18 \mathrm{mg} \mathrm{Mn}, 0.21 \mathrm{mg} \mathrm{Se}, 0.17 \mathrm{mg} \mathrm{I}, 3980 \mathrm{IU} \text { vitamin A, } 398 \mathrm{IU} \text { vitamin } \mathrm{D}_{3}, 38 \mathrm{mg} \text { vitamin E, } 1.5 \mathrm{mg} \\
\text { thiamin, } 3.6 \mathrm{mg} \text { riboflavin, } 2.1 \mathrm{mg} \text { pyridoxine, } 15 \mathrm{mg} \text { vitamin } \mathrm{B}_{12}, 0.15 \mathrm{mg} \text { biotin, } 11 \mathrm{mg} \text { pantothenic acid, } 15 \mathrm{mg} \text { niacin } \\
1.5 \mathrm{mg} \text { folic acid, and } 1.5 \mathrm{mg} \text { vitamin } \mathrm{K} \text {. }\end{array}$} \\
\hline
\end{tabular}

pairs, and these were assigned to five dietary treatments: 1) non-acidified basal diet and diets containing 2) lactic acid, 3) formic acid, 4) calcium formate, or 5) sodium benzoate according to an incomplete block design (Plan 11.2; Cochran and Cox 1957). Piglet pairs were housed in pens measuring $0.78 \times 1.68 \mathrm{~m}\left(0.68 \mathrm{~m}^{2}\right.$ of solid concrete floor and $0.63 \mathrm{~m}^{2}$ of plastic slatted floor) throughout the trial, which started at weaning and was continued until the piglets were 58 days old. Wood shavings were used as bedding material.

The composition of the basal diet is presented in Table 1. The acidified diets were prepared by supplementing the basal diet with $8 \mathrm{~g} \mathrm{~kg}^{-1}$ of lactic acid (80-85\%), formic acid (80-90\%), calcium formate, or sodium benzoate. Experimental diets were available ad libitum from gravity flow feeders. Before weaning, piglets were offered the basal diet ad libitum starting from the age of 14 days. Feed disappearance was determined 7 days after weaning and at the age of 51 and 58 days. Piglets were weighed at birth, weaning, and at the age of 51 and 58 days.

\section{Chemical analyses}

Feed samples were ground to pass through a 1$\mathrm{mm}$ sieve before analysis. Dry matter content was determined by drying at $103^{\circ} \mathrm{C}$ for $16 \mathrm{~h}$. Nitrogen was determined with the Dumas method using a Leco FP-428 N analyser (Leco Corp., St Joseph, USA). Dietary $\mathrm{pH}$ was measured in a mixture of $20 \mathrm{~g}$ feed and $100 \mathrm{ml}$ water $15 \mathrm{~min}$ utes after having been mixed with a whirl mixer for $20 \mathrm{sec}$. Dietary buffering capacity was determined as the amounts of $0.1 \mathrm{M} \mathrm{HCl}$ required 
Partanen, K. et al. Weaned piglets offered diets containing organic acids

to lower the $\mathrm{pH}$ of a mixture of $5 \mathrm{~g}$ feed and 50 $\mathrm{ml}$ water to 4 and 3 . Lactic acid was analysed according to Haacker et al. (1983) and benzoic acid according to a modified method of Plasser and Klostermeyer (1988). Formic acid was measured by spectrophotometry using a commercial kit and according to the manufacturer's instructions (Cat. No. 979 732, Boehringer Mannheim GmbH, Mannheim, Germany).

\section{Calculations and statistical analyses}

In Experiment 1, each individual test diet's relative preference $(\%)$ was calculated by dividing the feed intake in that diet (kg per piglet) by the total ingested in the two test diets (kg per piglet) offered simultaneously in the pair combination. The differences in feed intake and relative preference (the $\arcsin (\mathrm{X})$ value of the relative preference) between the study's diet pairs were tested by means of a t-test (Snedecor and Cochran 1989). The diet selection paths of each litter were described by plotting the cumulative differences between the feed intakes $(a-b)$ against the cumulative total feed intake $(a+b)$ as described by Kyriazakis et al. (1990). Performance data were analysed using the GLMprocedure of SAS (SAS 1998) and the following model (Snedecor and Cochran 1989):

$\mathrm{Y}_{\mathrm{ij}}=\mu+t_{\mathrm{i}}+\varepsilon_{\mathrm{ij}}$

where $t_{\mathrm{i}}$ is the fixed effect of treatment $i$ ( $i=$ $1, \ldots 6)$ and $\varepsilon_{\mathrm{ij}}$ is the normally distributed error with a mean of 0 and the variance $\sigma^{2}$. The litter was the experimental unit.

In Experiment 2, feed intake and performance data were analysed with the MIXED procedure of SAS (SAS 1998) using REML estimation and the following model (Snedecor and Cochran 1989):

$\mathrm{Y}_{\mathrm{ijk}}=\mu+a_{\mathrm{i}}+l(a)_{\mathrm{ij}}+t_{\mathrm{k}}+(a \times t)_{\mathrm{ik}}+\varepsilon_{\mathrm{ijk}}$

where $a_{\mathrm{i}}$ is the fixed effect of weaning age, $l(a)_{\mathrm{j}}$ is the random effect of litter within weaning age, $t_{\mathrm{k}}$ is the fixed effect of dietary treatment, $(a \times t)_{\mathrm{ik}}$ is the interaction between weaning age and dietary treatment, and $\varepsilon_{\mathrm{ijk}}$ is the normally distributed error with a mean of 0 and the variance $\sigma^{2}$. To test the effect of weaning age, $l(a)_{\mathrm{j}}$ was used as an error term. The pen with two pigs was the experimental unit. Organic-acid-supplemented diets were compared to the non-acidified control diet with the Dunnett test.

\section{Results and discussion}

The analysed chemical composition of the experimental diets is shown in Table 2. Dietary formic acid supplementation resulted in the greatest decrease in dietary $\mathrm{pH}$, followed by lactic acid and calcium formate supplementation, whereas sodium benzoate supplementation slightly increased dietary $\mathrm{pH}$. Dietary lactic and formic acid supplementations resulted in similar decreases in dietary buffering capacity, whereas calcium formate and sodium benzoate supplementations increased dietary buffering capacity. This is in accordance with the results of Roth and Kirchgessner (1989), who reported that dietary $\mathrm{pH}$ was decreased more by lactic and formic acid than calcium formate and that calcium formate supplementation increased the dietary buffering capacity.

In Experiment 1, the average consumption of creep feed from day 14 to weaning at day 30 was small, 94 g per piglet (s.d. 96.5), but highly variable, ranging from 0 to $458 \mathrm{~g}$ per piglet. Several studies have reported enormous variation in creep feed consumption before weaning. Barnett et al. (1989) found that total creep feed consumption varied from 13 to $194 \mathrm{~g}$ per piglet from day 10 to weaning at day 28, while Pajor et al. (1991) found a range in individual intake from 13 to 1911 g per piglet in the 14-day period before weaning. In this study, no correlation was found between creep feed consumption and birth or weaning weight of piglets (Table 3), which is in accordance with the results of Appleby et al. (1991). According to Pluske et al. (1995), the potential contribution of creep feed is from 1 to 
Vol. 11 (2002): 107-119.

Table 2. Analysed composition, $\mathrm{pH}$, and buffering capacity of basal and organic-acid-supplemented diets in Experiments 1 and 2 .

\begin{tabular}{|c|c|c|c|c|c|}
\hline Diet & $\mathrm{BD}$ & $\mathrm{L}$ & $\mathrm{F}$ & $\mathrm{CaF}$ & $\mathrm{NaB}$ \\
\hline \multicolumn{6}{|l|}{ Experiment 1} \\
\hline Dry matter, $\mathrm{g} \mathrm{kg}^{-1}$ & 887 & 882 & 882 & 884 & 880 \\
\hline Ash, $\mathrm{g} \mathrm{kg}^{-1} \mathrm{DM}$ & 54 & 54 & 55 & 57 & 56 \\
\hline Crude protein, $\mathrm{g} \mathrm{kg}^{-1} \mathrm{DM}$ & 204 & 203 & 211 & 208 & 203 \\
\hline Lactic acid, $\mathrm{g} \mathrm{kg}^{-1} \mathrm{DM}$ & - & 8.33 & - & - & - \\
\hline Formic acid, $\mathrm{g} \mathrm{kg}^{-1} \mathrm{DM}$ & - & - & 7.41 & 6.11 & - \\
\hline Benzoic acid, $\mathrm{g} \mathrm{kg}^{-1} \mathrm{DM}$ & - & - & - & - & 7.19 \\
\hline $\mathrm{pH}$ & 5.82 & 5.31 & 4.90 & 5.51 & 5.85 \\
\hline \multicolumn{6}{|c|}{ Buffering capacity, meq kg-1 DM } \\
\hline $\mathrm{pH} 4$ & 252 & 209 & 202 & 254 & 412 \\
\hline pH 3 & 545 & 495 & 493 & 623 & 642 \\
\hline \multicolumn{6}{|l|}{ Experiment 2} \\
\hline Dry matter, $\mathrm{g} \mathrm{kg}^{-1}$ & 880 & 841 & 868 & 846 & 846 \\
\hline Ash, $\mathrm{g} \mathrm{kg}^{-1} \mathrm{DM}$ & 51 & 57 & 57 & 60 & 63 \\
\hline Crude protein, $\mathrm{g} \mathrm{kg}^{-1} \mathrm{DM}$ & 212 & 217 & 210 & 216 & 216 \\
\hline Lactic acid, $\mathrm{g} \mathrm{kg}^{-1} \mathrm{DM}$ & - & 8.42 & - & - & - \\
\hline Formic acid, $\mathrm{g} \mathrm{kg}^{-1} \mathrm{DM}$ & - & - & 7.50 & 5.40 & - \\
\hline Benzoic acid, $\mathrm{g} \mathrm{kg}^{-1} \mathrm{DM}$ & - & - & - & - & 8.13 \\
\hline $\mathrm{pH}$ & 5.48 & 5.14 & 4.89 & 5.32 & 5.53 \\
\hline \multicolumn{6}{|c|}{ Buffering capacity, meq $\mathrm{kg}^{-1} \mathrm{DM}$} \\
\hline pH 4 & 166 & 80 & 84 & 144 & 154 \\
\hline pH 3 & 331 & 254 & 293 & 361 & 287 \\
\hline
\end{tabular}

$\mathrm{BD}=$ basal diet, $\mathrm{L}=$ lactic acid, $\mathrm{F}=$ formic acid, $\mathrm{CaF}=$ calcium formate, $\mathrm{NaB}=$ sodium benzoate, $\mathrm{DM}=\mathrm{dry}$ matter.

$17 \%$ of the daily energy intake of nursing piglets. There may be some benefit from feeding creep feed to nursing piglets, but evidence for its effect on weaning weight or post-weaning performance is limited. One reason for the equivocal performance results could be the high variability in creep feed consumption both among and within litters (Pajor et al. 1991). In the study of Bruininx et al. (2001b), piglets that ate creep feed during the suckling period ate more and performed better during the post-weaning period than those that had consumed no creep feed.

The development of feed consumption during the 21-d experimental period is shown in Figure 1. The increase in daily feed consumption was small (less than $30 \mathrm{~g} \mathrm{~d}^{-1}$ ) during the days 3 to 6 after weaning, and feed consumption did not start to increase substantially until 9 days after weaning. This plateau in the development of daily feed consumption coincided with post- weaning diarrhoea, which was observed in the majority of litters. Feed consumption during the first post-weaning week correlated positively with creep feed consumption before weaning $(r$ $=0.62, \mathrm{P}<0.001)$, which is in accordance with the results of Appleby et al. (1991) and Bruininx et al. (2001b). However, when three litters in which the creep feed consumption was over $160 \mathrm{~g}$ per piglet were excluded from the data, no correlation was found between pre- and postweaning feed consumption. No correlation was found between weaning weight and feed consumption during the first week after weaning. In the study of Bruininx et al. (2001a), piglets weaned at an average body weight of $6.7 \mathrm{~kg} \mathrm{had}$ higher initial feed intakes than their counterparts weaned at an average body weight of 7.9 and $9.3 \mathrm{~kg}$, but the daily increase in feed intake and total post-weaning feed consumption was similar in these groups. There was a strong positive 
Partanen, K. et al. Weaned piglets offered diets containing organic acids

Table 3. Correlations among variables based on litter means ( $\mathrm{n}=30$ litters $)$.

\begin{tabular}{|c|c|c|c|c|c|c|}
\hline & $\begin{array}{l}\text { Birth } \\
\text { weight }\end{array}$ & $\begin{array}{c}\text { Pre-weaning } \\
\text { feed } \\
\text { intake }\end{array}$ & $\begin{array}{l}\text { Pre-weaning } \\
\text { weight gain }\end{array}$ & $\begin{array}{c}\text { Weaning } \\
\text { weight }\end{array}$ & $\frac{\text { First week }}{\text { Feed intake }}$ & $\frac{\text { after weaning }}{\text { Weight gain }}$ \\
\hline Pre-weaning feed intake & -0.01 & & & & & \\
\hline Pre-weaning weight gain & 0.23 & 0.08 & & & & \\
\hline Weaning weight & $0.43^{*}$ & 0.08 & $0.97 * * *$ & & & \\
\hline \multicolumn{7}{|l|}{ First week after weaning } \\
\hline Feed intake & 0.20 & $0.62 * * *$ & -0.23 & -0.17 & & \\
\hline Weight gain & 0.09 & $0.39 *$ & -0.30 & -0.26 & $0.85^{* * *}$ & \\
\hline \multicolumn{7}{|l|}{ Whole post-weaning period } \\
\hline Feed intake & $0.40^{*}$ & $0.43^{*}$ & -0.04 & 0.06 & $0.81 * * *$ & $0.63 * * *$ \\
\hline Weight gain & 0.32 & $0.36^{*}$ & -0.17 & -0.10 & $0.79 * * *$ & $0.87 * * *$ \\
\hline
\end{tabular}

Significance: $*(\mathrm{P}<0.05)$ and $* * *(\mathrm{P}<0.001)$.

correlation between feed consumption and weight gain during the first post-weaning week and during the whole experiment (Table 3). Piglets that learn to eat immediately after weaning and gain weight during the first post-weaning week perform better during the subsequent periods, which translates to a several day lead in reaching slaughter weight (Pluske et al. 1995). It can take quite a long time before piglets start to eat after weaning. In the study of Bruininx et al. (2001a), $47 \%$ of piglets had not started to eat

\section{$\mathrm{kg} /$ piglet/d}

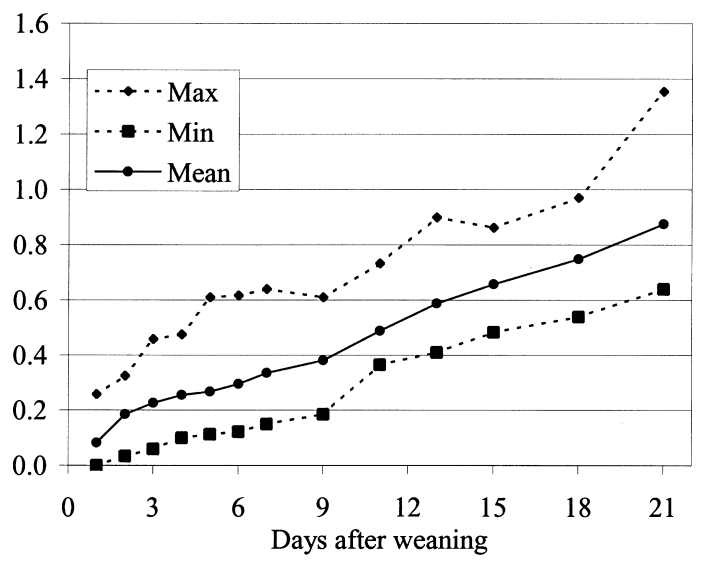

Fig. 1. Daily feed consumption of weaned piglets during the $21-d$ post-weaning period based on the means of the 30 litters used in Experiment 1. during the first $4 \mathrm{~h}$ after weaning, and $11 \%$ of piglets had not consumed any feed yet even $28 \mathrm{~h}$ after weaning.

No significant differences were found in the performance results of piglets given a choice of different organic-acid-supplemented diets (Table 4). In general, the average growth rate remained relatively low, less than $300 \mathrm{~g} \mathrm{~d}^{-1}$. This probably resulted from the high incidence of post-weaning diarrhoea; 21 out of 30 litters were medicated for post-weaning diarrhoea, which lasted on average for 6 days. There was no difference between the treatments in the incidence of post-weaning diarrhoea. The total consumption and relative preferences of the organic-acidsupplemented diets offered in free-choice settings are presented in Table 5. The consumption of feeds or their relative preferences did not differ between feeders in any of the experimental treatments or in the whole trial $(\mathrm{P}>0.05$, results not shown). No significant differences were observed in total consumption or relative preferences between diets supplemented with lactic acid and formic acid, lactic acid and calcium formate, lactic acid and sodium benzoate, and formic acid and calcium formate. Piglets offered diets supplemented with formic acid and sodium benzoate or calcium formate and sodium benzoate preferred diets with sodium benzoate to those with formic acid $(\mathrm{P}<0.10)$ or calcium formate $(\mathrm{P}<0.05)$. 
Vol. 11 (2002): 107-119.

Table 4. Performance and feed consumption of weaning piglets offered organic-acid-supplemented diets in a free-choice setting in Experiment 1.

\begin{tabular}{|c|c|c|c|c|c|c|c|}
\hline $\begin{array}{l}\text { Free choice } \\
\text { Treatment }^{1}\end{array}$ & $\begin{array}{c}\mathrm{L} / \mathrm{F} \\
1\end{array}$ & $\begin{array}{c}\mathrm{L} / \mathrm{CaF} \\
2\end{array}$ & $\begin{array}{c}\mathrm{L} / \mathrm{NaB} \\
3\end{array}$ & $\begin{array}{c}\mathrm{F} / \mathrm{CaF} \\
4\end{array}$ & $\begin{array}{c}\mathrm{F} / \mathrm{NaB} \\
5\end{array}$ & $\begin{array}{c}\mathrm{CaF} / \mathrm{NaB} \\
6\end{array}$ & SEM $^{2}$ \\
\hline \multicolumn{8}{|l|}{ Piglets per litter } \\
\hline At weaning & 10.0 & 9.8 & 10.2 & 10.2 & 10.0 & 11.0 & \\
\hline $7 \mathrm{~d}$ after weaning & 10.0 & 9.6 & 10.2 & 10.0 & 9.8 & 10.6 & \\
\hline $21 \mathrm{~d}$ after weaning & 9.8 & 9.4 & 10.0 & 9.8 & 9.4 & 10.6 & \\
\hline \multicolumn{8}{|l|}{ Weight, kg } \\
\hline At weaning & 9.2 & 8.7 & 8.4 & 8.3 & 8.9 & 8.7 & 0.47 \\
\hline $7 \mathrm{~d}$ after weaning & 10.0 & 9.0 & 9.1 & 9.1 & 9.7 & 9.9 & 0.48 \\
\hline $21 \mathrm{~d}$ after weaning & 15.0 & 13.8 & 13.8 & 14.1 & 15.0 & 14.8 & 0.72 \\
\hline \multicolumn{8}{|l|}{ Weight gain, $\mathrm{g} \mathrm{d}^{-1}$} \\
\hline 0-7 d after weaning & 121 & 41 & 105 & 116 & 114 & 171 & 46.3 \\
\hline 0-21 d after weaning & 278 & 246 & 258 & 276 & 291 & 291 & 29.0 \\
\hline \multicolumn{8}{|l|}{ Feed consumption, $\mathrm{g} \mathrm{d}^{-1}$} \\
\hline 0-7 d after weaning & 253 & 191 & 235 & 265 & 206 & 261 & 40.1 \\
\hline 0-21 d after weaning & 513 & 473 & 513 & 560 & 496 & 514 & 31.1 \\
\hline \multicolumn{8}{|l|}{$\mathrm{Kg}$ feed per kg gain } \\
\hline $0-21 \mathrm{~d}$ after weaning & 1.87 & 2.02 & 2.06 & 2.04 & 1.71 & 1.77 & 0.158 \\
\hline
\end{tabular}

Table 5. Consumption and relative preference of the experimental diets offered in a free-choice setting to weaned piglets during 21-d post-weaning period in Experiment 1.

\begin{tabular}{|c|c|c|c|c|c|c|c|c|c|c|}
\hline \multirow[b]{2}{*}{ Treatment $^{1}$} & \multirow{2}{*}{$\begin{array}{c}\begin{array}{c}\text { Free } \\
\text { choice }\end{array} \\
\mathrm{tt}^{1} \quad \mathrm{a} / \mathrm{b}\end{array}$} & \multicolumn{2}{|c|}{$\begin{array}{c}\text { Feed consumption } \\
\mathrm{kg} / \text { piglet }\end{array}$} & \multirow[b]{2}{*}{$t$} & \multirow[b]{2}{*}{ Signif. $^{2}$} & \multicolumn{3}{|c|}{$\begin{array}{c}\text { Relative preference } \\
\%\end{array}$} & \multirow[b]{2}{*}{$t$} & \multirow[b]{2}{*}{ Signif. $^{2}$} \\
\hline & & $\mathrm{a}$ & $\mathrm{b}$ & & & $\mathrm{a}$ & $\mathrm{b}$ & s.d. & & \\
\hline 1 & $\mathrm{~L} / \mathrm{F}$ & $5.62 \pm 1.24$ & $5.62 \pm 1.04$ & 0.660 & & 52.3 & 47.7 & 7.9 & 0.655 & \\
\hline 2 & $\mathrm{~L} / \mathrm{CaF}$ & $5.37 \pm 1.38$ & $4.50 \pm 1.42$ & 0.915 & & 55.6 & 44.4 & 14.5 & 0.868 & \\
\hline 3 & $\mathrm{~L} / \mathrm{NaB}$ & $5.03 \pm 2.71$ & $5.70 \pm 3.30$ & 0.256 & & 48.0 & 52.0 & 29.5 & 0.129 & \\
\hline 4 & $\mathrm{~F} / \mathrm{CaF}$ & $5.44 \pm 2.51$ & $6.03 \pm 2.74$ & 0.266 & & 47.6 & 52.4 & 24.3 & 0.225 & \\
\hline 5 & $\mathrm{~F} / \mathrm{NaB}$ & $3.22 \pm 1.48$ & $6.69 \pm 1.91$ & 2.635 & $\mathrm{o}$ & 32.6 & 67.4 & 15.7 & 2.455 & $\mathrm{o}$ \\
\hline 6 & $\mathrm{CaF} / \mathrm{NaB}$ & $2.73 \pm 1.42$ & $7.67 \pm 2.44$ & 3.161 & $*$ & 27.0 & 73.0 & 15.5 & 3.300 & $*$ \\
\hline
\end{tabular}

$\mathrm{L}=$ lactic acid, $\mathrm{F}=$ formic acid, $\mathrm{CaF}=$ calcium formate, $\mathrm{NaB}=$ sodium benzoate.

Five entire litters per treatment.

$2 t_{0.10(4)}=2.132$, and $t_{0.05(4)}=2.776$. Significance: $\mathrm{o}(\mathrm{P}<0.10)$ and $*(\mathrm{P}<0.05)$.

Diet selection paths of individual litters (Fig. 2) show that when piglets were offered diets supplemented with lactic acid or formic acid, none of the litters developed a preference for either of the diets, and the cumulative difference was less than $2 \mathrm{~kg}$ of feed by the end of the trial.
When diets supplemented with either lactic acid or calcium formate were offered, two litters out of five seemed to develop a slight preference for the lactic acid (cumulative difference over $2 \mathrm{~kg}$ ). When diets supplemented with either lactic acid or sodium benzoate were tested, one litter had a 


\section{AGRICULTURAL AND FOOD SCIENCE IN FINLAND}

\section{Partanen, K. et al. Weaned piglets offered diets containing organic acids}

strong preference for the former, and three litters for the sodium benzoate. Diets supplemented with formic acid or calcium formate were equally acceptable for two litters, while the former diet was preferred by two litters, and the latter by one. When the diet supplemented with sodium benzoate was offered together with diets supplemented with formic acid or calcium formate, three and four litters, respectively, out of five developed a strong preference for the sodium benzoate supplemented diet.

Previous studies have shown that weaned piglets are able to discriminate between different cereals and protein sources as well as diets of different lysine content (Ermer et al. 1994, Bruneau and Chavez 1995, Kirchgessner et al. 1999). In our study, weaned piglets preferred sodium benzoate to formic acid and calcium formate, which indicates that weaned piglets are able to differentiate between diets supplemented with different organic acids. This is not surprising since the pig tongue is known to possess a large number of taste buds, three to four times more than the human tongue (Chamorro et al. 1993, Danilova et al. 1999). Among the various taste stimuli tested in the study of Danilova et al. (1999), citric acid elicited the largest response in the chorda tympani proper nerve, which conveys the information from the fungiform taste buds. This indicates that citric acid creates a distinct taste quality in pigs. In the study of Henry et al. (1985), piglets preferred non-acidified diets to those supplemented with citric or formic acid, but no difference was observed in the palatability of the organic-acid-supplemented diets.

Of the investigated acids, formic acid has a strong pungent odour, while its calcium salt is odourless or has a sweet caramel-like odour (Kirchgessner and Roth 1987). However, no difference was found in the palatability of diets supplemented with formic acid or calcium formate. Lactic acid has a pleasant sour odour, and diets with naturally high lactic acid content have been shown to be palatable to piglets (Mikkelsen and Jensen 1997). The reason for the preference for sodium benzoate remains unknown. In hu- man panels, benzoic acid was found to be pungent (prickling) and slight sour, while sodium benzoate has been reported as sweet, salty, and bitter (Otero-Losada 1999). Weaned piglets have been shown to prefer diets with high salt content (Falkowski et al. 1998).

The performance response of weaned piglets offered single non-acidified or organic-acid-supplemented diets in Experiment 2 is presented in Table 6 . No significant weaning age $\times$ dietary treatment interactions were observed, and thus only the main effects are shown. Despite of a 10-day difference in the weaning age, no significant difference was found in the weight of piglets at weaning or at the age of 58 days. Birth weight was higher in litters weaned at 28 days of age than in those weaned at 38 days of age (1.9 vs. $1.5 \mathrm{~kg}, \mathrm{P}<0.01)$, which could be the major reason that there was a small difference in weaning weight. Although piglets weaned at the age of 38 days consumed more feed per day during the first week of and throughout the whole trial than those weaned at the age of 28 days ( $P$ $<0.001$ ), no significant difference was observed in the growth performance or feed conversion ratio of the piglets. There was no difference in daily feed consumption between piglets receiving non-acidified and organic-acid-supplemented diets $(P>0.05)$. The growth rate of piglets fed diets supplemented with calcium formate was slower than that of piglets fed a non-acidified control diet. In addition, the feed conversion ratio and the incidence of post-weaning diarrhoea tended $(\mathrm{P}=0.06)$ to be higher than in the control treatment. The performance of piglets offered other organic-acid-supplemented diets did not differ from that of piglets fed the non-acidified control diet $(\mathrm{P}>0.05)$. The considerably higher feed consumption and conversion ratio compared to Experiment 1 indicates that there was some feed wastage due to feeders. It is possible that some acids may increase feed wastage. However, because feed consumption was equally high in the control group, it seems more likely that the feeders used in Experiment 2 were responsible for high feed wastage. Furthermore, the piglets were housed in pairs, and the amount 


\section{AGRICULTURAL AND FOOD SCIENCE IN FINLAND}

Vol. 11 (2002): 107-119.

a)

Cumulative difference L - F, kg

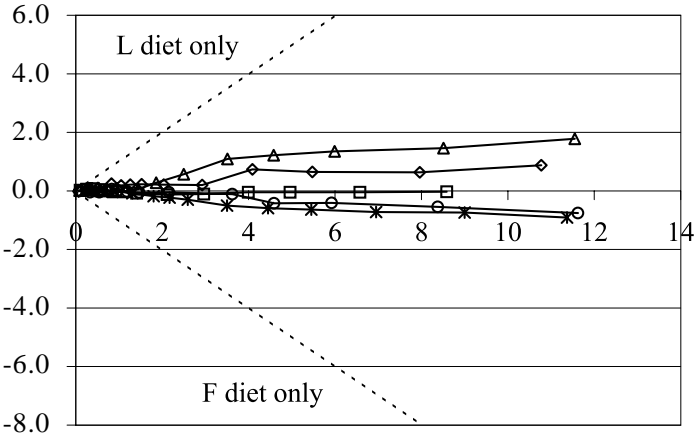

Cumulative sum $\mathrm{L}+\mathrm{F}, \mathrm{kg}$

c)

Cumulative difference L - NaB,

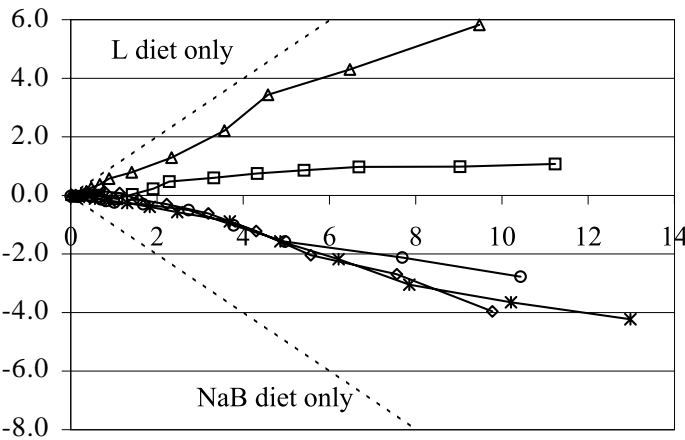

Cumulative sum $\mathrm{L}+\mathrm{NaB}, \mathrm{kg}$

e)

Cumulative difference $\mathrm{F}-\mathrm{NaB}, \mathrm{kg}$

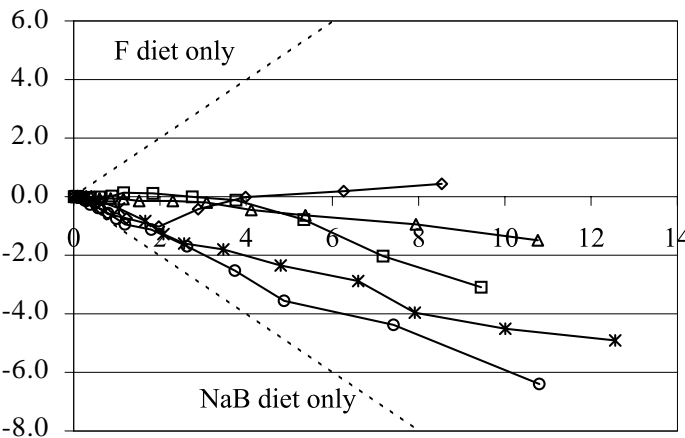

Cumulative sum $\mathrm{F}+\mathrm{NaB}, \mathrm{kg}$ b)

Cumulative difference $\mathrm{L}-\mathrm{CaF}, \mathrm{kg}$

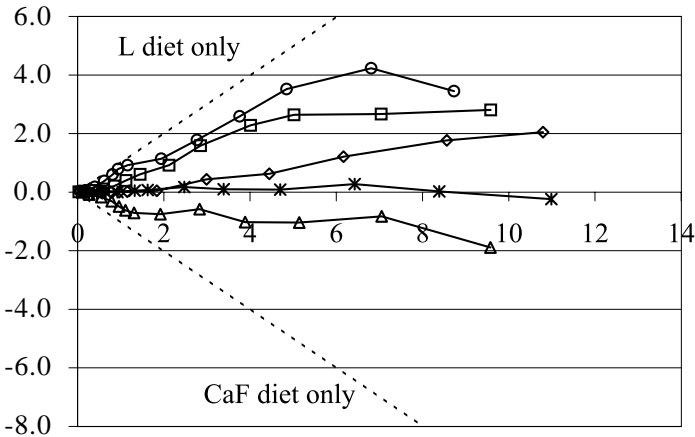

Cumulative sum $\mathrm{L}+\mathrm{CaF}, \mathrm{kg}$

d)

Cumulative difference $\mathrm{F}$ - $\mathrm{CaF}, \mathrm{kg}$

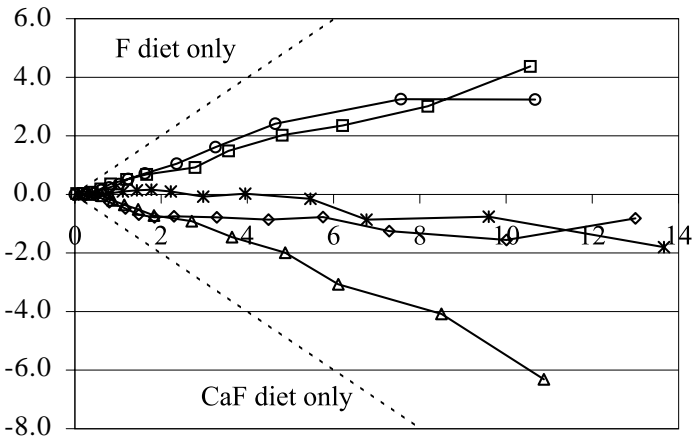

Cumulative sum $\mathrm{F}+\mathrm{CaF}, \mathrm{kg}$

f)

Cumulative difference $\mathrm{CaF}-\mathrm{NaB}, \mathrm{kg}$

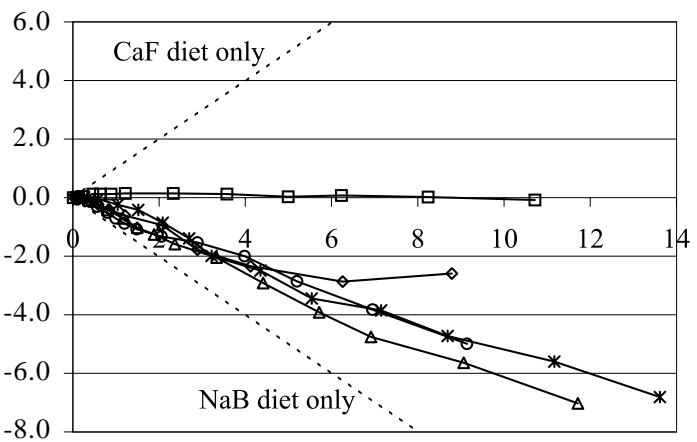

Cumulative sum $\mathrm{CaF}+\mathrm{NaB}, \mathrm{kg}$

Fig. 2. The paths of diet selection of weaned piglets given a choice between weaner diets supplemented with a) lactic acid or formic acid, b) lactic acid or calcium formate, c) lactic acid or sodium benzoate, d) formic acid or calcium formate, e) formic acid or sodium benzoate, and $\mathrm{f}$ ) calcium formate or sodium benzoate. Each line refers to a litter. $\mathrm{L}=$ lactic acid, $\mathrm{F}=$ formic acid, $\mathrm{CaF}=$ calcium formate, and $\mathrm{NaB}=$ sodium benzoate. 
Partanen, K. et al. Weaned piglets offered diets containing organic acids

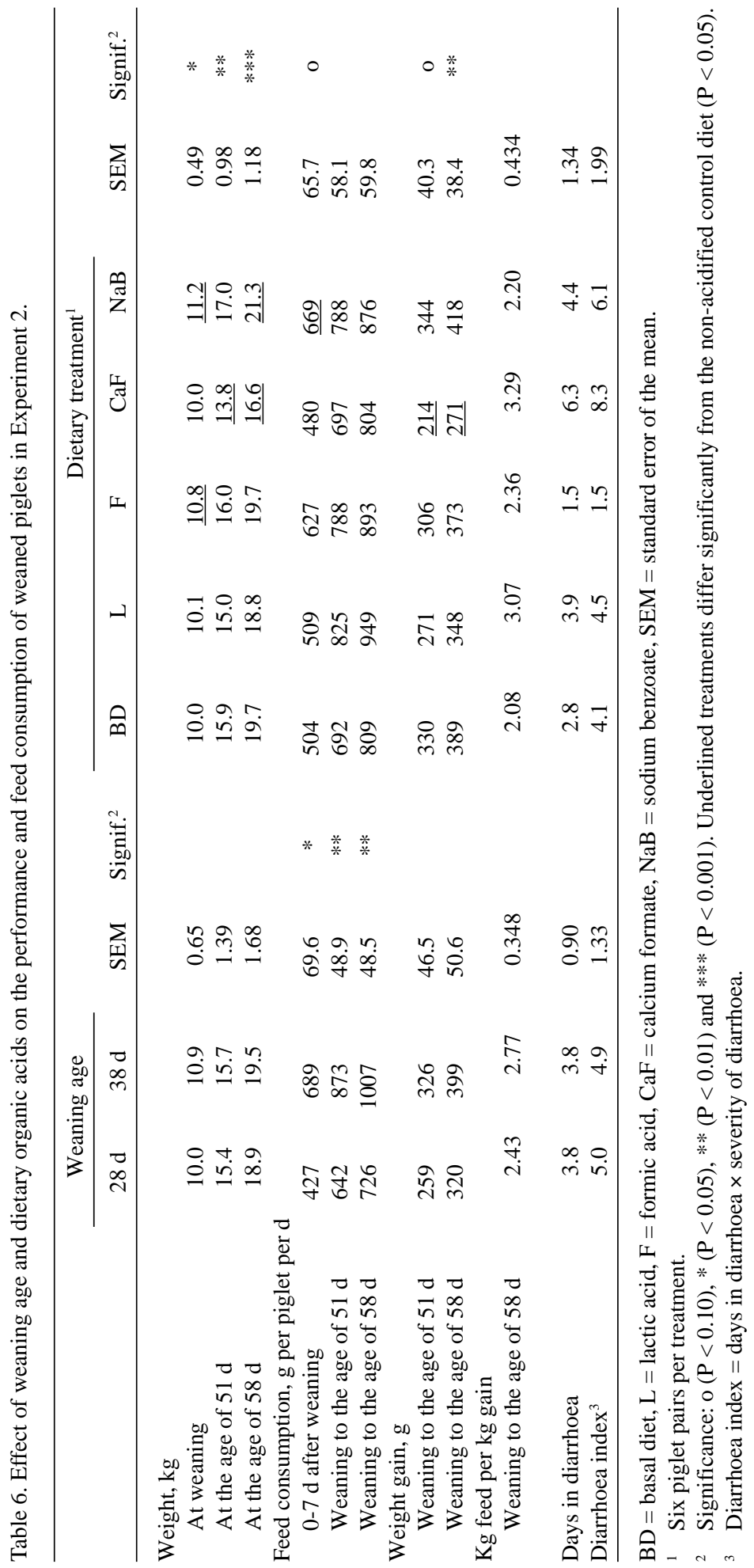


Vol. 11 (2002): 107-119.

of feed wastage per piglet probably becomes greater than in trials with entire litters.

According to Partanen (2001), several studies have shown that dietary formic acid supplementation enhances the performance of weaned piglets. Dietary levels of 6-12 $\mathrm{g} \mathrm{kg}^{-1}$ have increased post-weaning feed consumption, whereas higher levels (18-24 $\mathrm{g} \mathrm{kg}^{-1}$ ) have resulted in reduced feed intake compared to a non-acidified control diet (Eckel et al. 1992). In the study of Kirchgessner and Roth (1987), ad libitum feed consumption of weaned piglets was decreased by $3-5 \%$ in diets supplemented with calcium formate $\left(9-27 \mathrm{~g} \mathrm{~kg}^{-1}\right)$. Dietary calcium formate had no significant influence on the growth performance of piglets, but it improved their feed conversion ratio $(\mathrm{P}<0.05)$ and reduced the frequency of diarrhoea compared to that of piglets fed the non-acidified control diet. The negative effect of dietary calcium formate supplementation on the performance of weaned piglets could be related to the increased dietary calcium content. Calcium formate contains about $330 \mathrm{~g} \mathrm{~kg}^{-1}$ of calcium, and the supplementation of $8 \mathrm{~g} \mathrm{~kg}^{-1}$ feed increased the dietary calcium content from 9 to $11 \mathrm{~g} \mathrm{~kg}^{-1}$ feed. According to Pallauf et al. (1993), calcium formate supplementation of diets already meeting the calcium requirement of piglets had a negative effect on feed intake, weight gain, and feed conversion ratio. Particularly the digestibility of fat was decreased. Therefore, the total dietary calcium level should not exceed the optimum when diets are supplemented with calcium formate. Dietary lactic acid supplementation $\left(8-24 \mathrm{~g} \mathrm{~kg}^{-1}\right)$ increased feed consumption of weaned piglets by $6 \%$ compared to a non-acidified control diet (Roth et al. 1993). Information about the effect of dietary sodium benzoate supplementation on weaned piglet performance is scarce. Sodium benzoate supplementation has been shown to enhance the performance of growing-finishing pigs, for which the main interest in dietary benzoate supplementation is to lower urinary $\mathrm{pH}$ and to thus reduce ammonia emission (van der Peet-Schwering et al. 1999).

\section{Conclusions}

The results showed that there may be some differences in the palatability of different organicacid-supplemented diets. When allowed to choose, piglets preferred diets supplemented with sodium benzoate to diets supplemented with formic acid or calcium formate. The acceptability of diets supplemented with lactic acid, formic acid, or calcium formate was similar for weaned piglets. Growth performance was reduced by dietary calcium formate supplementation, while the results of diets supplemented with other acids did not differ significantly from those of the non-acidified control diet. The frequency of post-weaning diarrhoea was highest in diets supplemented with calcium formate and lowest in diets with formic acid.

Acknowledgements. The authors wish to thank Kemira Chemicals, Ltd., Formics, Finland for financial support for this study.

\section{References}

Appleby, M.C., Pajor, E.A. \& Fraser, D. 1991. Effects of management options on creep feeding by piglets. Animal Production 53: 361-366.

Barnett, K.L., Kornegay, E.T., Risley, C.R., Lindemann, M.D. \& Schurig, G.G. 1989. Characterization of creep feed consumption and its subsequent effects on im- mune response, scouring index and performance of weanling pigs. Journal of Animal Science 67: 26982708.

Bruininx, E.M.A.M., van der Peet-Schwering, C.M.C., Schrama, J.W., Vereijken, P.F.G., Vesseur, P.C., Everts, H., den Hartog, L.A. \& Beynen, A.C. 2001 a. 


\section{Partanen, K. et al. Weaned piglets offered diets containing organic acids}

Individual measured feed intake characteristics and growth performance of group-housed weanling pigs: Effect of sex, initial body weight, and body weight distribution within groups. Journal of Animal Science 79: 301-308.

Bruininx, E.M.A.M., van der Peet-Schwering, C.M.C. \& Swinkels, J.W.G.M. 2001b. Creep feed consumption and individual food intake characteristics of group housed weaned pigs. In: Proceedings of the British Society of Animal Science 2001. p. 34.

Bruneau, C.D. \& Chavez, E.R. 1995. Dietary preferences for cereals of nursing and weaned piglets. Livestock Production Science 41: 225-231.

Chamorro, C.A., de Paz, P., Fernández, J.G. \& Anel, L. 1993. Fungiform papillae of the pig and the wild boar analysed by scanning electron microscopy. Scanning Microscopy 7: 313-322.

Cochran, W.G. \& Cox, G.M. 1957. Experimental Designs. Wiley, New York. 611 p.

Danilova, V., Roberts, T. \& Hellekant, G. 1999. Responses of single taste fibres and whole chorda tympani and glossopharyngeal nerve in the domestic pig, Sus scrofa. Chemical Senses 24: 301-316.

Eckel, B., Kirchgessner, M. \& Roth, F.X. 1992. Zum Einfluss von Ameisensäure auf tägliche Zunahmen, Futteraufname, Futterverwertung und Verdaulichkeit. Journal of Animal Physiology and Animal Nutrition 67: 93-100.

Ermer, P.M., Miller, P.S. \& Lewis, A.J. 1994. Diet preference and meal patterns of weanling pigs offered diets containing either spray-dried porcine plasma or dried skim milk. Journal of Animal Science 72: 15481554.

Falkowski, J., Kozera, W. \& Bugnacka, D. 1998. Effect of different fodder salt $(\mathrm{NaCl})$ content of diets on feed preferences of weaned pigs. Natural Sciences 1:5158.

Haacker, K., Block, H.J. \& Weissbach, F. 1983. Zur kolorimetrischen Milchsäurebestimmung in Silagen mit $\mathrm{p}$ Hydroxydiphenyl. Archieves für Tierernährung 33: 505-512.

Henry, R.W., Pickard, D.W. \& Hughes, P.E. 1985. Citric acid and fumaric acid as food additives for earlyweaned piglets. Animal Production 40: 505-509.

Kirchgessner, M. \& Roth, F.X. 1987. Use of formates in the feeding of piglets. 1. Communication: Calcium formate. Landwirtschaftliche Forschung 40: 141-152.

Kirchgessner, M., Roth, F.X. \& Eidelsburger, U. 1993. Zur nutritiven Wirksamkeit von Weinsäure und Äpfelsäure in der Ferkelaufzucht. Journal of Animal Physiology and Animal Nutrition 70: 216-224.

Kirchgessner, M., Roth, F.X. \& Paulicks, B.R. 1995. Zur nutritiven Wirkung von Sorbinsäure in der Ferkelaufzucht. Journal of Animal Physiology and Animal Nutrition 74: 235-242.

Kirchgessner, M., Stangl, G.I. \& Roth, F.X. 1999. Evidence of a specific dietary selection for lysine by the piglet.
Journal of Animal Physiology and Animal Nutrition 81: 124-131.

Kyriazakis, I., Emmans, G.C. \& Whittemore, C.T. 1990. Diet selection in pigs: choices made by growing pigs given foods of different protein concentrations. Animal Production 51: 189-199.

Mikkelsen, L.L. \& Jensen, B.B. 1997. Effect of fermented liquid feed (FLF) on growth performance and microbial activity in the gastrointestinal tract of weaned piglets. In: Laplace, J.P. et al. (eds.). Digestive Physiology in Pigs. EAAP Publication no. 88. p. 639-642.

Otero-Losada, M.E. 1999. A kinetic study on benzoic acid pungency and sensory attributes of benzoic acid. Chemical Sences 24: 245-253.

Pajor, E.A., Fraser, D. \& Kramer, D.L. 1991. Consumption of solid food by suckling pigs: individual variation and relation to weight gain. Applied Animal Behaviour Science 32: 139-151.

Pallauf, J. \& Hüter, J. 1993. Studies on the influence of calcium formate on growth, digestibility of crude nutrients, nitrogen balance and calcium retention in weaned piglets. Animal Feed Science and Technology 43: 65-76.

Partanen, K. 2001. Organic acids - their efficacy and modes of action in pigs. In: Piva, A. et al. (eds.). Gut environment of pigs. Nottingham University Press, Nottingham. p. 201-217.

Plasser, A.J. \& Klostermeyer, H. 1988. NPN-Komponenten der Milch als analytische Indikatoren in Lebensmitteln. Zeitschrift für Lebensmittel-Untersuchung und -Forschung 187: 552-557.

Pluske, J.L., Williams, I.H. \& Aherne, F.X. 1995. Nutrition of the neonatal pig. In: Varley, M.A. (ed.). The Neonatal Pig - Development and Survival. CAB International, Oxon. p. 187-235.

Ravindran, V. \& Kornegay, E.T. 1993. Acidification of weaner pig diets: A review. Journal of the Science of Food and Agriculture 62: 313-322.

Roth, F.X. \& Kirchgessner, M. 1989. Bedeutung von pHWert und Pufferkapazität des Futters für die Ferkelfütterung. 1. Mitteilung: pH-Wert und Pufferkapazität von Futtermischungen bei Einsatz von organischen Säuren. Landwirtschaftliche Forschung 42: 157-166.

Roth, F.X., Kirchgessner, M. \& Eidelsburger, U. 1993. Zur nutritiven Wirksamkeit von Milchsäure in der Ferkelaufzucht. Agribiological Research 46: 229-239.

SAS 1998. SAS/STAT User's Guide (Release 6.03). SAS Institute, Inc. Cary, NC. 1686 p.

Snedecor, G.W. \& Cochran, W.G. 1989. Statistical Methods. lowa State University Press, Ames, Iowa. $503 \mathrm{p}$.

van der Peet-Schwering, C.M.C., Verdoes, N. \& Plagge, J.G. 1999. Influence of benzoic acid in the diet on performance and urine $\mathrm{pH}$ of growing-finishing pigs. Research report P 5.8, Rosmalen, Research Institute for Pig Husbandry. $24 \mathrm{p}$. 


\title{
AGRICULTURAL AND FOOD SCIENCE IN FINLAND
}

Vol. 11 (2002): 107-119.

\section{SELOSTUS}

\author{
Orgaanisten happojen vaikutus porsasrehun maittavuuteen \\ Kirsi Partanen, Hilkka Siljander-Rasi ja Kaija Suomi \\ MTT (Maa- ja elintarviketalouden tutkimuskeskus)
}

\begin{abstract}
Valinta- ja kasvatuskokeissa selvitettiin porsasrehun maitohappo-, muurahaishappo-, kalsiumformiaatti- ja natriumbentsoaattilisäysten $(8 \mathrm{~g} / \mathrm{kg}$ rehua) vaikutusta vieroitettujen porsaiden rehun syöntiin. Valintakokeessa oli 30 pahnuetta (306 porsasta), jotka vieroitettiin 30 päivän iässä. Orgaanista happoa sisältäviä rehuja testattiin pareittain ja tutkitut kuusi yhdistelmää olivat maitohappo/muurahaishappo, maitohappo/ kalsiumformiaatti, maitohappo/natriumbentsoaatti, muurahaishappo/kalsiumformiaatti, muurahaishappo/ natriumbentsoaatti ja kalsiumformiaatti/natriumbentsoaatti. Vieroituksesta 21 päivän ajan porsailla oli mahdollisuus syödä vapaasti automaatista jompaa kumpaa tarjolla ollutta orgaanista happoa sisältävää rehua. Porsaat söivät mieluummin natriumbentsoaattia kuin muurahaishappoa tai kalsiumformiaattia si-
\end{abstract}

sältävää rehua. Maitohappoa, muurahaishappoa tai kalsiumformiaattia sisältäneiden rehujen maittavuudessa ei ollut eroja. Kasvatuskokeessa oli 60 porsasta 10 pahnueesta, jotka oli vieroitettu 28 tai 38 päivän iässä. Porsaat saivat syödä vapaasti lisäaineetonta tai maitohappoa, muurahaishappoa, kalsiumformiaattia tai natriumbentsoaattia sisältävää rehua vieroituksesta 58 päivän ikään. Lisäaineettoman ja orgaanisia happoja sisältäneiden rehujen kulutuksessa ei ollut eroja. Rehun kalsiumformiaattilisäys heikensi porsaiden kasvua lisäaineettomaan ruokintaan verrattuna. Muut happolisäykset eivät vaikuttaneet porsaiden kasvuun. Ripulia esiintyi eniten porsailla, joiden rehuun lisättiin kalsiumformiaattia, ja vähiten niillä, joiden rehuun lisättiin muurahaishappoa. 